\title{
Komunikasi dalam CSR Perusahaan: Pemberdayaan Masyarakat dan Membangun Citra Positif
}

\author{
${ }^{1}$ ANUAR RASYID, 2 AMIRUDDIN SALEH, \\ ${ }^{3}$ HAFIED CANGARA, ${ }^{4}$ WAHYU BUDI PRIATNA
}

\author{
${ }^{1}$ Fakultas Ilmu Komunikasi, Universitas Riau. Jl. HR. Soebrantas KM 12,5 Panam Pekanbaru \\ 2 Sains Komunikasi dan Pengembangan Masyarakat, IPB. Jl. Kamper, Kampus IPB Darmaga, Bogor. 16680 \\ ${ }^{3}$ Guru Besar Ilmu Komunikasi Universitas Hasanuddin. Jl. Perintis Kemerdekaan KM. 10 Makassar 90245 \\ ${ }^{4}$ Dosen Agribisnis Institut Pertanian Bogor. Jl. Kamper, Kampus IPB Darmaga, Bogor 16680 \\ ${ }^{1}$ anuarkmp03@yahoo.co.id, 2amiruddin@yahoo.co.id ${ }^{3}$ cangara_hafied@yahoo.com ${ }^{4}$ wahdiprit@gmail.com
}

\begin{abstract}
Community empowerment and positive image are desired of the company's CSR program. The purpose of this study was to analyze ( 1 ) the implementation of company's CSR communication PTPN V for community empowerment and building a positive image. ( 2 ) relationship among communication company's CSR PTPN $\vee$ with community empowerment and corporate image. Research using quantitative and survey techniques. The population in this study as many as 418 people. The sample in this study as many as 250 people. Sampling in this study conducted proportional sampling. The conclusions of this study is the implementation of CSR communication within the company PTPN $V$ for community empowerment and build a positive image is generally going well. Furthermore, there are very significant $(p<0.01)$ relationship among communicators, messages, channels with community empowerment and corporate image.
\end{abstract}

Keysword: communication, corporate social responsibility, community empowerment, positve image

Abstrak. Pemberdayaan masyarakat dan citra postif adalah yang diinginkan dari program
CSR perusahaan. Tujuan penulisan ini adalah menganalisis implementasi komunikasi dalam
CSR perusahaan PTPN V untuk pemberdayaan masyarakat dan membangun citra positif
dan hubungan komunikasi CSR perusahaan PTPN V dengan pemberdayaan masyarakat
dan citra perusahaan. Penelitian menggunakan kuantitatif dan teknik survei. Populasi pada
penelitian ini sebanyak 418 orang. Sedangkan sampel dalam penelitian ini sebanyak 250
orang. Pengambilan sampel pada penelitian ini dilakukan secara proporsional sampling.
Simpulan penelitian ini adalah implementasi komunikasi dalam CSR perusahaan PTPN V
untuk pemberdayaan masyarakat dan membangun citra positif secara umum berjalan
dengan baik. Selanjutnya terdapat hubungan yang sangat signifikan ( $\mathrm{p}<0,01$ ) antara
komunikator, pesan, saluran dengan pemberdayaan masyarakat dan citra perusahaan.

Kata kunci: Komunikasi, CSR, pemberdayaan masyarakat, citra positif

\section{Pendahuluan}

Pembangunan masyarakat merupakan amanat dari Undang-Undang Dasar 1945, oleh karena itu mesti menjadi fokus perhatian dan tanggung jawab semua pihak, baik pemerintah, dunia usaha (swasta dan koperasi), serta masyarakat. Korporasi atau perusahaan berkontribusi secara wajar di dalam pembangunan daerah sebagai implementasi tanggung-jawab sosialnya melalui Program Kemitraan Bina Lingkungan (PKBL/CSR). Program Kemitraan Bina Lingkungan (PKBL/CSR) merupakan salah satu model dari pemberdayaan masyarakat. Menurut konsepnya setiap perusahaan harus memegang prinsip-prinsip 3P (profit, people, and planet), yang selain mengejar keuntungan juga harus memperhatikan kesejahteraan masyarakat di sekitar kawasan wilayah kerja perusahaan, serta pelestarian dunia seisinya

Received: 9 Agustus 2015, Revision: 22 September 2015, Accepted: 7 Desember 2015

Print ISSN: 0215-8175; Online ISSN: 2303-2499. Copyright@2015. Published by Pusat Penerbitan Universitas (P2U) LPPM Unisba Terakreditasi SK Kemendikbud, No.040/P/2014, berlaku 18-02-2014 s.d 18-02-2019 
(Mardikanto, 2010: 329; Nasdian, 2014: 56). Peran dunia usaha cukup strategis melalui program CSR membantu pemerintah dalam menggerakkan, bahkan mempercepat laju roda perekonomian daerah. Sehingga pada gilirannya akan memberikan kontribusi terhadap peningkatan indeks daya beli karena berkurangnya angka pengangguran (Suherman, 2006).

Pelaksanaan PKBL/CSR di Indonesia dipayungi oleh Undang-Undang No. 40 tahun 2007, Pasal 74 yaitu Undang-Undang tentang Perseroan Terbatas. Dalam UndangUndang ini pada pasal 74 dinyatakan bahwa semua Perseroan Terbatas wajib hukumnya melaksanakan PKBL/CSR, sehingga tanggung sosial menjadi bagian dari rencana penganggaran perusahaan. Selanjutnya, Peraturan Menteri Negara Badan Usaha Milik Negara (BUMN) No: PER 05/ MBU/2007 tanggal 27 April 2007 Pasal 9. BUMN menyisihkan 1-2\% dari laba bersih untuk Program Kemitraan Bina Lingkungan (PKBL/CSR). Pengertian Program Kemitraan Bina Lingkungan telah dituangkan dalam surat Keputusan Menteri Badan Usaha Milik Negara tentang Program Kemitraan Badan Usaha Milik Negara dengan usaha kecil dan program bina lingkungan Nomor: KEP-236/ MBU/2003 tanggal 17 Juni 2003 pada pasal 1 ayat 4 yakni, "Program Bina Lingkungan adalah program pemberdayaan kondisi sosial masyarakat oleh BUMN di wilayah usaha BUMN tersebut melalui pemanfaatan dana dari bagian laba BUMN."

Kota Pekanbaru merupakan salah satu dari beberapa kabupaten/kota yang berada di sekitar PTPN V. Kota pekanbaru merupakan wilayah yang paling dekat dengan kantor pusat PTPN V dari beberapa kabupaten/kota yang lain. Bidang Sektor yang dibantu lebih beragam diterima oleh masyarakat yang ada di Kota Pekanbaru dibandingkan kabupaten/ kota yang lain.

Permasalahan yang terjadi pada program kemitraan di Kota Pekanbaru menurut data dan hasil wawancara dengan kepala bagian PKBL/CSR PTPN V Pekanbaru adalah secara umum terjadi penurunan dana yang disalurkan pada program kemitraan dari Tahun 2011 sampai Tahun 2014. Penurunan dana adalah sebagai berikut, penyaluran dana pinjaman program kemitraaan Kota Pekanbaru Tahun 2010 diberikan kepada 179 orang dengan jumlah dana sebanyak Rp 2.892.000.000, kemudian terjadi penurunan pada Tahun 2011 menjadi 132 orang dengan jumlah dana sebanyak Rp. 2.265.000.000. Pada 2012 menurun menjadi 85 orang dengan jumlah sebesar Rp 1.650.000.000. Masyarakat Kota Pekanbaru tidak mendapatkan bantuan sama sekali pada 2013. Selanjutnya, masyarakat Kota Pekanbaru pada 2014 mendapatkan bantuan sebanyak 22 orang. Jumlah bantuan pada Tahun 2014 sebanyak Rp. 520.000.000 (Dokumentasi PTPN V, 2014).

Permasalahan komunikasi CSR/PKBL diduga terjadi pada proses awal. Para pegawai PKBL/CSR hanya mengumumkan penerimaan proposal melalui Dinas Koperasi dan Usaha Mikro Kecil Menengah (UMKM). Masyarakat luas tidak mengetahui adanya pinjaman lunak yang dikucurkan oleh PTPN V. Masyarakat yang mendapatkan bantuan pinjaman lunak hanya masyarakat yang mempunyai kenalan dengan pegawai PTPN V. Selanjutnya, masyarakat yang pernah mendapatkan pinjaman sebelumnya atau permintaan dari dinas lain yang memerlukan. Hal ini sesuai juga dengan hasil pra survey dari 30 orang responden sekitar $80 \%$ atau 24 orang mengetahui informasi bantuan pinjaman lunak CSR PTPN $\vee$ melalui teman dan kenalan yang bekerja sebagai pegawai CSR PTPN V.

Komunikasi yang dilakukan oleh CSR PTPN V terhadap masyarakat adalah komunikasi searah dan top down, karena tidak melibatkan masyarakat untuk menentukan berbagai hal. Hal ini bertentangan dengan semangat komunikasi partisipatif yang dua arah (two way of communication). Hal ini berdasarkan hasil wawancara dengan ketua kelompok petani yang mendapatkan bantuan dari CSR PTPN V. Beliau mengatakan bahwa:

"Kami tidak pernah diajak untuk meren-
canakan program oleh pegawai CSR PTPN
V, Kami diminta membuat proposal dan
menyiapkan syarat-syarat untuk bantu-
an. Kemudian kami dipanggil setelah tem-
pat kami disurvei. Kalau kami mengikuti
syarat-syarat yang ditentukan maka kami
dapat bantuan, kalau tidak memenuhi
syarat-syarat otomatis kami tidak dapat"

Pemberdayaan masyarakat dalam bentuk pelatihan-pelatihan kepada masyarakat sangat sedikit. Hal ini terlihat dari survei dari 30 orang responden, sebanyak $73 \%$ atau 22 orang responden hanya mendapatkan pelatihan sekali selama bantuan dari CSR PTPN V. Hasil wawancara dengan salah seorang penerima bantuan sebagai berikut:

"Saya mendapatkan pelatihan manajemen keuangan pada awal menerima bantuan. Setelah itu saya tidak mendapatkan pelatihan ataupun seminar lagi." 
Fenomena permasalahan dari fakta dan data yang terlihat antara lain penurunan penyaluran dana pinjaman, informasi yang tidak merata bagi masyarakat sekitar Kota Pekanbaru dan komunikasi yang top down, tanpa melibatkan masyarakat dalam berbagai hal. Kemudian sedikitnya pelatihan dalam pemberdayaan masyarakat. Berdasarkan dari berbagai fenomena permasalahan yang telah dikemukakan, artikel ini bertujuan menganalisis implementasi komunikasi dalam CSR PTPN V untuk pemberdayaan masyarakat dan membangun citra positif dan menganalisa hubungan komunikasi dalam CSR dengan pemberdayaan masyarakat dan citra positif.

\section{Komunikasi dalam Corporate Social Responsibility}

Istilah komunikasi berasal dari bahasa latin yaitu Communicatio yang berarti pemberitahuan yang pertukaran, kata sifatnya Communis yang bermakna umum, bersama atau membangun kebersamaan atara dua orang atau lebih (Effendy, 2003:2; Wiryanto, 2005:6 ; Cangara,2013: 9 ; Mulyana, 2007: 41). Menurut, Everett M. Rogers dalam (Mulyana 2007: 151; Cangara 2012: 15), komunikasi adalah proses di mana suatu ide dialihkan dari sumber kepada suatu penerima atau lebih dimaksud untuk mengubah tingkah laku mereka. Dance dan Larson dalam Vardiansyah (2004: 113) berpendapat komunikasi adalah proses pertukaran informasi untuk mendapatkan saling pengertian.

Menurut Harold D. Laswell "komunikasi adalah proses penyampaian pesan oleh komunikator kepada komunikan melalui media yan menimbulkan efek tertentu (Effendy, 2003: 7).

"Paradigma Lasswell menyatakan: who, says what, in which channel, to whom with, what effect (siapa, mengatakan apa, melalui saluran apa, kepada siapa, dengan efek apa) hal tersebut menunjukkan bahwa komunikasi meliputi 5 unsur yaitu komunikator, pesan, komunikan, saluran, dan efek.

Komunikasi juga merupakan salah satu bidang yang dikaji dalam Corporate Social Responsibility (CSR). Corporate Social Responsibility (CSR) telah dibedah menjadi banyak komponen oleh banyak penulis, masing-masing dengan agenda yang berbeda. Hal ini termasuk istilah inklusif seperti tanggung jawab perusahaan, corporate citizenship, keberlanjutan, dan kinerja sosial perusahaan (Freeman \& Hasnaoui, 2011).

Istilah Corporate Social Responsibility telah ada lebih dari 70 tahun (Freeman \& Hasnaoui, 2011). Istilah ini digunakan secara sinonim oleh banyak ahli. Beberapa pendapat antara lain; keberlanjutan perusahaan adalah bagian dari CSR (Agle et al, 1999; Turban dan Greening 1997), CSR merupakan bagian dari etika (Argandona dan von Weltzien Hoivik 2010; Weitzner dan Darroch, 2009). Jain et al. (2011) mendefinisi CSR,

sebuah konsep yang komprehensif yang bertujuan sebagai praktek promosi bisnis yang bertanggung jawab yang terkait erat dengan strategi perusahaan.

Berbagai penelitan yang berkaitan dengan komunikasi CSR antara lain: Chaudhri dan Wang (2007) menganalisis komunikasi CSR yang dilakukan oleh 100 informasi teknologi (IT) perusahaan di India di situs perusahaan mereka, dengan fokus analisis pada dimensi keunggulan komunikasi, informasi, dan gaya presentasi. Kemudian, Birth_et al. (2008) mendeskripsikan tentang praktik komunikasi CSR perusahaan di antara 300 perusahaan di Swiss. Komunikasi CSR di Swiss tampaknya berkembang dengan baik, tetapi masih memiliki batas untuk pengembangan. Selanjutnya, Ligety (2009) meneliti komunikasi CSR, dengan kasus alasan-alasan perusahaan dalam rangka meningkatkan citra mereka sendiri untuk alasan pemasaran.

Nielsen and Thomsen (2009) mengkaji bagaimana CSR muncul dan dikomunikasikan dalam usaha kecil dan menengah. Komitmen karyawan dan penggunaan langsung wordof-mouth, menyebabkan komunikasi dengan stakeholder internal dan lokal memiliki platform yang bermanfaat mengadopsi komunikasi CSR strategis. Moreno and Capriotti (2009) memperdalam pemahaman situs web perusahaan yang digunakan tanggung jawab sosial perusahaan, corporate citizenship dan pembangunan berkelanjutan (CSR/CC/SD). Verboven (2011) menganalisis komunikasi tanggung jawab sosial perusahaan (CSR) dan citra perusahaan dalam industri kimia melalui slogan misi.

Tewari dan Dave (2012) menganalisis komunikasi Corporate Social Responsibility (CSR) yang dilakukan melalui penggunaan laporan keberlanjutan dan untuk membandingkan komunikasi CSR yang dilakukan oleh perusahaan India dan Perusahaan Multinasional (MNC) melalui media laporan keberlanjutan. Penelitian berkaitan dengan komunikasi CSR, Takano (2013) menguji industri makanan Jepang dalam menanggapi undang-undang pendidikan 
makanan 2005 melalui komunikasi CSR.

\section{Pemberdayaan Masyarakat}

Istilah pemberdayaan (empowerment) telah lahir semenjak pertengahan abad ke-17 dengan makna menanamkan kewenangan (to invest with authority) atau memberi kewenangan (authorize). Dalam pengertian umum pemberdayaan berarti untuk memungkinkan (to enable) atau mengijinkan (to permit), atau mengajarkan kepada seseorang unuk belajar memimpin dirinya sendiri (leading the people to learn to lead themselves). Dari banyak batasan, ada yang memfokuskan kepada pemberdayaan individu, yang berarti suatu proses untuk meningkatkan kemampuan individu. Seseorang dikatakan telah empowered adalah ketika ia telah dapat memimpin dirinya sendiri (Syahyuti, 2006: 20).

Pemberdayaan juga melibatkan aspek kognitif, psikomotorik, psikologis, ekonomi dan politik. Kemudian akses pada pengetahuan dan keterampilan (internal maupun eksternal) untuk menjaga stok modal alami dan lingkungan secara sinambung. Selanjutnya akses pada pelatihan keterampilan, teknikteknik pemecahan masalah, teknologi tepat guna dan informasi (Jahi, 2006: 50). Lebih lanjut, Suharto (2005: 58) menyatakan bahwa,

pemberdayaan menunjuk pada kemampuan orang memenuhi kebutuhan dasarnya sehingga mereka memiliki kebebasan, dalam arti bukan saja bebas mengemukakan pendapat, melainkan bebas dari kelaparan, kebodohan, dan kesakitan.

Komunikasi merupakan salah satu alat yang dapat berperanan penting dalam mengoptimalkan pemberdayaan. Kegiatan pemberdayaan masyarakat perlu dikomunikasikan dengan baik dan benar. Beberapa penelitian program CSR dengan tujuan pemberdayaan adalah sebagai berikut; (1) Hasil penelitian implementasi tanggung jawab sosial perusahaan (Corporate Social Responsibility) dalam pemberdayaan dan peningkatan kesejahteraan masyarakat: Kasus di Provinsi Lampung menunjukkan bahwa masyarakat berpersepsi bahwa CSR merupakan kegiatan perusahaan membantu masyarakat dalam bidang fisik, sosial, budaya, dan atau ekonomi agar masyarakat lebih berdaya dan mandiri sehingga mereka terbantu dalam meningkatkan kesejahteraannya (Sumaryo, 2009). (2) Selanjutnya, Situmeang (2012) menyatakan terdapat hubungan sangat nyata antara tingkat persepsi masyarakat dan tingkat keberdayaan masyarakat. (3) Hasbullah (2012) menyatakan bahwa CSR Pupuk Kaltim (PKT) berperan dalam pemberdayaan ekonomi. Kemudian, analisis hubungan antara tanggung jawab sosial perusahaan dan konsep pemberdayaan ekonomi di Afrika Selatan oleh Sharlene (2012) menyatakan bahwa para pimpinan perusahaan di Afrika Selatan berhasil memberdayakan ekonomi melalui komitmen mereka dalam mengimplementasikan CSR.

\section{Citra Perusahaan}

Jefkins (2004: 17) memberikan definisi citra adalah kesan seseorang atau individu tentang sesuatu yang muncul sebagai hasil dari pengetahuan dan pengalaman yang dimilikinya. Kotler (2005: 90) mengungkapkan bahwa citra merupakan seperangkat keyakinan, ide, dan kesan yang dimiliki seseorang terhadap suatu obyek. Citra berkaitan erat dengan suatu penilaian, tanggapan, opini, kepercayaan publik, asosiasi atau simbol-simbol tertentu terhadap suatu perusahaan. Citra tersebut dapat bersifat positif atau negatif. Moore (2004:17) menyatakan terdapat beberapa jenis citra (image), yakni: citra bayangan (mirror image), citra yang berlaku (current image), citra yang diharapkan (wish image), citra majemuk (multiple image), serta citra perusahaan (corporate image).

Citra perusahaan berkaitan dengan sosok perusahaan sebagai tujuan utamanya, bagaimana citra perusahaan yang positif lebih dikenal dan diterima oleh publiknya mungkin tentang sejarahnya, kualitas pelayanan prima, keberhasilan dalam bidang marketing dan berkaitan dengan kegiatan tanggungjawab sosial yang dilakukan (Ardianto, 2007: 137).

Hasil penelitian Cahyati (2008) menemukan bahwa melalui kegiatan CSR Pertamina UP III Bandung di bidang pendidikan, pelatihan, kesehatan, keagamaan yang dilaksanakan turut membentuk citra yang baik di mata masyarakat kepada perusahaan. Penelitian ini akan membahas citra perusahaan melalui kegiatan tanggungjawab sosial perusahaan (PKBL/CSR) dari aspek ekonomi, sosial dan lingkungan yang dilakukan oleh CSR PTPN V.

\section{Metode Penelitian}

Penelitian ini dilaksanakan di kawasan wilayah kerja PTPN V di Pekanbaru. Perseroan Terbatas Perkebunan Nasional 
(PTPN V) beralamat di Jl. Rambutan No. 43. Pekanbaru. Penelitian ini dilakukan pada masyarakat sekitar PTPN $V$ yang menerima bantuan program kemitraan CSR PTPN $\checkmark$ di Pekanbaru. Penelitian ini dirancang menggunakan pendekatan kuantitatif. Penelitian kuantitatif menggunakan survei korelasional. Pengumpulan data dilakukan melalui empat tahapan yaitu: (1) Survei pendahuluan terhadap 30 orang penerima bantuan CSR PTPN V; (2) Pengumpulan data primer yaitu menggunakan instrumen berupa kuesioner tertutup yang disebarkan kepada 250 orang responden. Kuesioner; (3) Wawancara terstruktur dilakukan terhadap kepala bagian CSR PTPN V Pekanbaru, Kepala Bagian Dinas Koperasi dan Usaha Menengah Kecil dan Mikro (UMKM) Propinsi Riau serta lima orang penerima bantuan CSR PTPN V; (4) Pengumpulan data sekunder yaitu datadata pendukung yang diperoleh dari pihakpihak dan lembaga-lembaga terkait yaitu CSR PTPN V, Dinas Koperasi dan Usaha Mikro Kecil Menengah (UMKM).

Populasinya adalah masyarakat yang menerima bantuan pinjaman lunak di Kota Pekanbaru pada Tahun 2010, 2011 2012, 2014 sebanyak 418 orang. Pengambilan sampel pada penelitian ini dilakukan secara proporsional sampling. Sampel diambil dalam persentasi yang sama yaitu $60 \%$. Secara terperinci populasi dan sampel terdapat pada Tabel 1.

Tabel 1

Tahun pemberian pinjaman, populasi, total sampel dan sampel

\begin{tabular}{ccc}
\hline $\begin{array}{c}\text { Tahun } \\
\text { pemberian } \\
\text { pinjaman }\end{array}$ & $\begin{array}{c}\text { Populasi } \\
\text { (orang) }\end{array}$ & Sampel (orang) \\
\hline 2010 & 179 & 107 \\
2011 & 132 & 79 \\
2012 & 85 & 51 \\
2014 & 22 & 13 \\
Total & 418 & 250 \\
\hline & & Data Olahan, 2015
\end{tabular}

Dalam menganalisis implementasi komunikasi dalam CSR PTPN V dimanfaatkan analisis deskriptif, uji korelasional Rank Spearman ( $r s$ ) dimanfaatkan untuk menganalisis hubungan antara komunikator, pesan, saluran dengan pemberdayaan masyarakat dan citra perusahaan. Data diolah dengan menggunakan perangkat lunak SPSS 21. Indikator pada penelitian adalah data ordinal dengan empat kategori yaitu sangat tinggi kategori empat, tinggi kategori tiga, agak rendah kategori dua, rendah kategori satu dan ditranformasi menjadi data interval. Hasil tranformasi data interval adalah sebagai berikut: rendah: $1-1,75$; agak rendah: 1,76 - 2,51; tinggi: 2,52 - 3,27; sangat tinggi: 3,28 - 4. Rumus tranformasi data pada Gambar 1.

$$
\text { Skor }(\mathrm{S})=\frac{\text { Perolehan nilai ordinal }- \text { nilai terendah data ordinal }}{\text { Nilai tertinggi data ordinal }- \text { nilai terrendah data ordinal }}
$$

Hasil dan Pembahasan Analisis Implementasi Komunikasi dalam CSR Perusahaan untuk Pemberdayaan Masyarakat dan Membangun Citra Positif

Pada tahapan pelaksanaan/ implementasi pihak-pihak yang terlibat terdiri atas; Direksi, Kabag, Kepala Urusan dan Asisten Urusan. Seluruh pihak yang terlibat pada tahap ketiga berjumlah sekitar 12 orang. Proses Pelaksanaan menjalankan hasil keputusan rapat sesuai dengan yang tertera dalam RKA. Kegiatan yang sampaikan dalam pelaksanaan adalah Program Kemitraan dan Bina Lingkungan. Kegiatan yang dilakukan pada tahap pelaksanaan antara lain; Penerimaan Proposal dari masyarakat. Survey, Pemberian Bantuan dan Pelatihan.

\section{Tahap Penerimaan Proposal}

Tahap ini Pegawai PKBL/CSR PTPN V bekerjasama dengan Pegawai Dinas Koperasi dan UMKM Propinsi, Kota dan Kabupaten. Masyarakat bisa memberikan proposal kepada Pegawai Dinas Koperasi dan UMKM. Setelah terkumpul sesuai dengan yang diinginkan Pegawai PKBL/CSR PTPN V maka Proposal diserahkan kepada mereka. Masyarakat juga dapat langsung mengantarkan proposal kepada pegawai PTPN V. Pegawai PTPN V juga bisa menghubungi masyarakat yang sudah pernah mendapatkan bantuan. Biasanya masyarakat yang lancar pembayaran cicilan pada tahap pertama, kemudian pada tahap kedua pegawai PTPN V menghubungi mereka langsung, guna mendapatkan pinjaman pada tahap berikutnya.

Pada tahap ini masyarakat disamping mengajukan proposal juga harus menyiapkan syarat-syarat untuk menerima bantuan. Adapun persyaratan-persyaratan yang disiapkan untuk mengikuti program ini diantaranya, membuat proposal permohonan bantuan, kartu keluarga (KK), sebagai agunan antara lain; surat tanah, surat rumah, BPKB kendaraan dan lain-lain. 
Pada tahap proposal ini terjadi komunikasi langsung dan komunikasi tidak langsung. Proses komunikasi tidak langsung yaitu dapat dilihat dari proses ketika pegawai PKBL/CSR PTPN V menjadikan Pegawai Dinas Koperasi dan UMKM sebagai perantara untuk menerima proposal dari masyarakat. Sedangkan Proses komunikasi langsung ketika masyarakat datang kepada Pegawai PKBL/CSR PTPN V untuk mengantarkan proposal, atau pegawai PKBL/CSR PTPN V menelpon langsung masyarakat yang sudah pernah dapat untuk memperpanjang bantuan pada tahap berikutnya.

\section{Tahap Survei}

Masyarakat yang sudah memberikan proposal dan bersedia melengkapi syaratsyarat yang diberikan oleh pegawai PKBL/ CSR PTPN V, maka dilakukan survei ke lokasi atau rumah masyarakat calon penerima bantuan tersebut. Pada tahap ini berlangsung komunikasi tatap muka atau komunikasi antarpribadi. Pegawai CSR PTPN V dan masyarakat calon penerima bantuan berperan sebagai komunikator dan komunikan secara bergantian. Komunikasi tatap muka ini sangat efektif untuk mengetahui informasi secara langsung tentang masyarakat yang akan menerima bantuan. Bagi masyarakat komunikasi antarpribadi ini dapat mendekatkan hubungan dengan pihak pegawai CSR PTPN $\mathrm{V}$ dan bertanya langsung tentang program kemitraan secara lengkap dan jelas.

\section{Tahap pemberian bantuan dan pelatihan}

Kemudian setelah proposal masyarakat dinyatakan diterima, pihak CSR PTPN V melakukan pertemuan dengan masyarakat untuk menjelaskan mengenai program CSR kepada masyarakat penerima. Masyarakat dikumpulkan di dalam satu tempat secara bersamaan yaitu di gedung pertemuan yang sudah direncanakan. Adapun unsurunsur yang hadir yaitu dari pihak PTPN V, Kepala Dinas Koperasi dan UMKM dan masyarkat. Media yang digunakan dalam komunikasi publik/ ceramah/ pidato oleh pegawai yang bertugas menjelaskan program. menggunakan pengeras suara, power point/ slide untuk presentasi dan In focus.

Hal-hal yang disampaikan mengenai visi dan misi perusahaan, visi dan misi program PKBL/ CSR, syarat yang dipenuhi ketika menerima bantuan, motivasi usaha, manfaat program, cara mengembangkan dan memanfaatkan dana serta tanggung jawab yang harus dipatuhi masyarakat penerima bantuan dana PKBL/CSR. Masyarakat juga mendapatkan pelatihan manajemen keuangan yang baik oleh pegawai PTPN V.

Tahap ini terkadang membahas juga evaluasi pelaksanaan penerima $\mathrm{PKBL} / \mathrm{CSR}$ sebelumnya, respon masyarakat penerima ketika pelaksanaan dan dampak pelaksanaan program pada masyarakat penerima sebelumnya sesuai keadaan dan kondisi.

Hasil wawancara dengan berbagai responden masyarakat bahwa komunikator mempunyai karakteristik yang baik. Karakter komunikator sebagai ethos yang terdiri dari pikiran baik (good sense), akhlak yang baik (good moral character) dan maksud yang baik (good will) dimiliki oleh komunikator CSR PTPN V. Kemudian dari sisi kredibilitas (credibility), Daya Tarik Sumber dan Kekuasaan (power) komunikator CSR PTPN V juga memilikinya.

Hasil wawancara dengan responden masyarakat, dari sisi pesan atau informasi yang disampaikan oleh sumber/komunikator merupakan pesan yang mudah untuk dimengerti oleh komunikan/ penerima. Hal ini terlihat dengan telah tercipta persamaan makna dan pengertian diantara pegawai PTPN V dengan masyarakat. Pegawai PTPN V sebagai komunikator sudah melakukan pertukaran pesan akan mempertimbangkan pesan yang diterimanya tersebut berguna bagi masyarakat. Pesan yang berguna tersebut dijadikan referensi dalam menjalankan berbagai kegiatan yang dibantu oleh PTPN V. Sebagaimana Sperber dan Wilson (1986) dalam Situmeang (2012) menyatakan bahwa ada lima hal yang terkait dengan mutu pesan yang dapat dipertimbangkan oleh penerima yaitu (1) pesan sesuai atau relevan dengan kebutuhan penerima, relevan dengan konteks dan budaya yang berlaku bagi pengguna, (2) ada kebaruan/novelty dalam materi pesan tersebut, (3) dapat dipercaya, (4) mudah dimengerti, dan (5) dapat memecahkan permasalahan pengguna. Kemudian, sebaiknya masyarakat dilibatkan dalam perencanaan program (Sumaryo, 2009)

Dari sisi saluran, hasil wawancara menunjukkan bahwa pegawai PTPN $\mathrm{V}$ hanya menggunakan saluran interpersonal dan media publik dengan masyarakat. Sedangkan saluran media massa dan media kelompok diabaikan. Tingkat efektivitas penyaluran bantuan program kemitraan CSR PTPN V adalah sebagai berikut Tahun 2011 sabanyak 
70,34\%, Tahun 2012 sebanyak 77,17\% dan Tahun 2013 sebanyak 81,46\% (Laporan Manajemen PKBL 2013). Melalui data ini dapat dilihat masih ada peluang sekitar 20-30\% lagi untuk membantu masyarakat. Cangara (2012: 140) menyatakan saluran terbaik untuk menyampaikan pesan secara luas dan serempak adalah media massa. Untuk pemanfaatan saluran, Cangara (2012: 137-141) membagi media komunikasi kedalam empat kelompok. Empat kelompok media atau saluran tersebut adalah: media antarpribadi, media kelompok, media publik dan media massa.

Dari sisi komunikan hasil wawancara dengan responden terlihat bahwa penerima/ komunikan dalam hal ini masyarakat sudah menerima pesan dari komunikator dengan baik. Penerima pesan dalam komunikasi ini berupa individu, kelompok dari masyarakat. Komunikator sudah mengetahui siapa yang akan menjadi khalayaknya sebelum proses komunikasi berlangsung, sehingga proses komunikasi bisa berlangsung dengan baik dan pesan komunikasi bisa tersampaikan. Pegawai CSR PTPN V sebagai komunikator sudah mempelajari karakteristik fisik dan psikologis masyarakat. Sehingga penerimaan, interpretasi dan evaluasi pesan-pesan bisa dilaksanakan dengan baik.

Dari sisi akibat/ efek/ pengaruh adalah hasil yang terjadi pada pihak penerima/ komunikan. Dalam program CSR efek yang diingankan adalah pemberdayaan masyarakat. Oleh karena itu aspek-aspek yang dijadikan tujuan program CSR untuk memberdayakan masyarakat perlu diperhatikan dengan baik. Efek atau hasil akhir dari suatu komunikasi, merupakan sikap dan tingkah laku individu, sesuai atau tidak sesuai dengan yang diinginkan oleh komunikator. Jika sikap dan tingkah laku individu tersebut sesuai, maka komunikasi dapat dikatakan berhasil, demikian pula sebaliknya (Hamidi, 2007: 72).

Hasil wawancara dengan responden menunjukkan bahwa masyarakat menjadi berdaya dengan adanya program CSR PTPN V. Kebutuhan sehari-hari baik sandang, pangan dan papan sudah terpenuhi, pengetahuan, sikap, keterampilan dan tindakan masyarakat dalam memahami usaha mereka sudah meningkat. Mereka menjadi mandiri dan hubungan dengan masyarakat sekitar menjadi baik dan harmonis.

Dari sisi akibat/ efek/ pengaruh adalah hasil yang terjadi pada pihak perusahan/ komunikator adalah citra perusahaan. Hasil wawancara dengan responden menunjukkan bahwa masyarakat menilai baik terhadap citra ekonomi dan sosial. Sedangkan dari aspek lingkungan masyarakat tidak pernah diberikan penyuluhan dan pelatihan. Masyarakat juga kurang tahu keadaan lingkungan PTPN V, karena sebahagian besar domisili masyarakat Pekanbaru tidak berdekatan langsung dengan kantor, pengolahan sawit, perkebunan PTPN V.

\section{Analisis Korelasi Komunikasi dalam CSR Perusahaan dengan Pember- dayaan Masyarakat dan Membangun Citra Positif}

Hasil penelitian di lapangan dari kuesioner yang disebarkan kepada 250 orang responden. Kuesioner tersebut berisikan pernyataan dan pertanyaan yang harus dijawab oleh responden. Setelah kuesioner dijawab oleh responden, kemudian data hasil kuesioner tersebut dibahas dalam Tabel 2 . sampai Tabel 6, Adapun pembahasan sebagai berikut:

Tabel 2. menunjukkan bahwa peubah kominikator berada pada kategori tinggi/ baik dengan nilai rataan sebesar 3.02 atau $75,50 \%$. Seluruh indikator pada peubah komunikator secara keseluruhan berada pada kategori tiga (3). Hal ini menunjukkan masyarakat penerima dana program kemitraan secara keseluruhan memiliki penilaian yang baik terhadap komunikator.

Kemudian, peubah pesan berada pada kategori tinggi/ baik dengan nilai rataan sebesar 2,96 atau $74 \%$. Sebagian besar indikator pada peubah pesan secara keseluruhan berada pada kategori tiga (3), Hal ini menunjukkan masyarakat penerima dana program kemitraan secara keseluruhan memiliki penilaian yang baik terhadap pesan yang mereka terima. Kecuali, indikator perencanaan program berada pada kategori rendah yaitu 1,35 atau $33,75 \%$. Hal ini didukung hasil wawancara dengan kepala bagian CSR PTPN V yang mengatakan bahwa mereka hanya menjalankan program yang sudah direncanakan oleh para pimpinan perusahaan. Selanjutnya, wawancara dengan ketua kelompok petani yang mendapatkan bantuan dari CSR PTPN V. Beliau mengatakan bahwa:

"Kami tidak pernah diajak untuk merencanakan program oleh pegawai CSR PTPN $\mathrm{V}$, Kami diminta membuat proposal dan menyiapkan syarat-syarat untuk bantuan. Kemudian kami dipanggil setelah tempat kami disurvei. Kalau kami mengikuti syarat-syarat yang ditentukan maka kami dapat bantuan, kalau tidak memenuhi 
Tabel 2

Nilai Indikator komunikator, pesan dan saluran pada program kemitraan

\begin{tabular}{|c|c|c|}
\hline Indikator/Peubah & Rataan* & $\begin{array}{c}\text { Persen } \\
(\%)\end{array}$ \\
\hline Kredibilitas & 2,81 & 70,25 \\
\hline Daya Tarik Sumber & 3,06 & 76,50 \\
\hline Kekuasaan & 3,15 & 78,75 \\
\hline Pikiran baik & 2,97 & 74,25 \\
\hline Akhlak Yang baik & 2,97 & 74,25 \\
\hline Maksud yang baik & 3,18 & 79,50 \\
\hline Rataan Peubah Komunikator & 3,02 & 75,50 \\
\hline Perencanaan program & 1,35 & 33,75 \\
\hline Pesan relevan & 3,20 & 80 \\
\hline Unsur kebaruan & 3,17 & 79,25 \\
\hline Dapat dipercaya & 3,22 & 80,50 \\
\hline Mudah dimengerti & 3,17 & 79,25 \\
\hline Membantu menyelesaikan masalah & 3,16 & 79 \\
\hline Rataan Peubah Pesan & 2,96 & 74 \\
\hline Antarpribadi & 3,13 & 78.25 \\
\hline Kelompok & 1,67 & 41,75 \\
\hline Publik & 2,98 & 74,50 \\
\hline Media massa & 1,63 & 40,75 \\
\hline Rataan Peubah Saluran & 2,35 & 58.75 \\
\hline
\end{tabular}

Keterangan: *Rendah : 1-1,75; agak rendah: 1,76-2,51; Tinggi: 2,52-3,27 Sangat tinggi: 3,28-4. Hasil Olahan 2015

syarat-syarat otomatis kami tidak dapat"

Selanjutnya, peubah saluran Tabel 2. memperlihatkan bahwa peubah saluran berada pada kategori agak rendah/ kurang baik dengan nilai rataan sebesar 2.35 atau $58,75 \%$. Hal ini menunjukkan masyarakat penerima dana program kemitraan secara keseluruhan memiliki penilaian yang kurang baik terhadap saluran yang mereka terima. Berdasarkan hasil wawancara dengan kepala bidang CSR PTPN V menyatakan bahwa CSR PTPN V dalam melaksanakan programnya tidak menggunakan media massa, baik media cetak maupun elektronik (radio, TV lokal dan nasional) dan media kelompok.

Tabel 3. menunjukkan bahwa peubah pemberdayaan masyarakat berada pada kategori tinggi/ baik dengan nilai rataan sebesar 3.16 atau $79 \%$. Seluruh indikator pada peubah pemberdayaan masyarakat berada pada kategori tiga (3). Hal ini menunjukkan sebagian besar masyarakat memiliki penilaian yang baik terhadap pemberdayaan masyarakat yang dilakukan CSR/PKBL PTPN V. Masyarakat penerima bantuan CSR/PKBL PTPN V merasakan efek positif terhadap pemenuhan kebutuhan dasar, pengetahuan, keterampilan, sikap dan tindakan mereka. Selanjutnya, Tabel
3 memperlihatkan bahwa peubah citra perusahaan berada pada kategori tinggi/ baik dengan nilai rataan sebesar 2,87 atau $71,75 \%$. Hal ini membuktikan bahwa masyarakat penerima bantuan dana menilai perusahaan PTPN V memiliki citra positif yaitu pada indikator ekonomi dan sosial. Sedangkan pada indikator lingkungan masyarakat menilai pada kategori agak rendah 2,22 atau 55,50\%.

Tabel 4 menunjukkan bahwa terdapat hubungan yang sangat signifikan $(p<0,01)$ antara komunikator, pesan, saluran dengan pemberdayaan masyarakat dan citra perusahaan. Secara rinci dapat terlihat hubungan yang sangat signifikan $(p<0,01)$ terdapat antara komunikator dengan Pemberdayaan masyarakat. menunjukkan bahwa terdapat hubungan yang sangat signifikan $(p<0,01)$ antara peubah komunikator dengan peubah Pemberdayaan Masyarakat. Hal ini berarti semakin baik komunikator dalam berkomunikasi maka semakin berdaya masyarakat. Selanjutnya, terdapat hubungan yang sangat signifikan $(p<0,01)$ antara peubah komunikator dengan peubah citra perusahaan. Hal ini bermakna bahwa komunikator yang baik akan mampu menigkatkan citra positif terhadap perusahaan. 
MIMBAR, Vol. 31, No. 2 (Desember, 2015): 507-518

Tabel 3

Nilai Indikator Pemberdayaan Masyarakat dan Citra perusahaan

\begin{tabular}{lll}
\hline Indikator/ Peubah & Rataan* & $\begin{array}{l}\text { Persen } \\
(\%)\end{array}$ \\
\hline Memenuhi kebutuhan dasar & 3,25 & 81.25 \\
Memiliki pengetahuan & 3,03 & 75.75 \\
Memiliki keterampilan & 3,19 & 75,75 \\
Memiliki sikap & 3,12 & 78 \\
Tindakan & 3,21 & 80,25 \\
Rataan Peubah Pemberdayaan Masyarakat & 3.16 & 79 \\
Ekonomi & 3,10 & 77,50 \\
Sosial & 3,28 & 82 \\
Lingkungan & 2,22 & 55,50 \\
Rataan Peubah Citra Perusahaan & 2,87 & 71,75 \\
\hline
\end{tabular}

Keterangan: *Rendah : 1-1,75; agak rendah: 1,76-2,51; Tinggi: 2,52-3,27 Sangat tinggi: 3,28-4. Hasil Olahan 2015

Tabel 4

Koefisien korelasi peubah komunikasi dalam CSR perusahaan dengan pemberdayaan masyarakat dan citra perusahaan

\begin{tabular}{lll}
\hline Peubah & $\begin{array}{l}\text { Pemberdayaan } \\
\text { Masyarakat }\left(\mathrm{Y}_{1}\right)\end{array}$ & Citra Perusahaan $(\mathrm{Y} 2)$ \\
\hline Komunikator $\left(\mathrm{X}_{1}\right)$ & $0,819^{* *}$ & $0.561^{* *}$ \\
Pesan $\left(\mathrm{X}_{2}\right)$ & $0.633^{* *}$ & $0.412^{* *}$ \\
Saluran $\left(\mathrm{X}_{3}\right)$ & $0.293^{* *}$ & $0.206^{* *}$ \\
\hline
\end{tabular}

Hasil Olahan 2015

Keterangan $* *)$ Sig taraf 0.1

Kemudian, terdapat hubungan yang sangat signifikan $(p<0,01)$ antara peubah pesan dengan peubah pemberdayaan masyarakat. Hal ini berarti semakin baik pesan yang disampaikan maka akan semakin mampu meningkatkan pemberdayaan masyarakat. Berikutnya, terdapat hubungan yang sangat signifikan $(p<0,01)$ antara peubah pesan dengan peubah citra perusahaan. Hal ini menunjukkan bahwa semakin baik pesan yang disampaikan akan berefek yang baik pula terhadap citra perusahaan.

Kemudian terdapat hubungan yang sangat signifikan $(p<0,01)$ antara peubah saluran dengan peubah pemberdayaan masyarakat. Hal ini bermakna bahwa semakin tepat saluran yang digunakan maka akan semakin baik pemberdayaan masyarakat. Akhirnya, terdapat hubungan yang sangat signifikan $(p<0,01)$ antara peubah saluran dengan peubah citra perusahaan. Hal ini mengindikasikan semakin baik dan tepat yang digunakan maka semakin baik citra perusahaan di mata masyarakat.

Tabel 5. memerlihatkan bahwa terdapat hubungan yang sangat signifikan $(p<0,01)$ antara sebagian besar indikator komunikator dengan indikator pemberdayaan masyarakat. Hal ini mengindikasikan bahwa indikator komunikator yang baik akan mampu meningkatkan indikator pemberdayakan masyarakat dari aspek pemenuhan kebutuhan dasar, peningkatan pengetahuan, peningkatan keterampilan, sikap dan tindakan yang lebih baik.

Kemudian, Tabel 5. menunjukkan bahwa terdapat hubungan yang sangat signifikan $(p<0,01)$ antara sebagian besar indikator pesan dengan indikator pemberdayaan. Hal ini mengindikasikan bahwa semakin baik indikator pesan maka mampu meningkatkan indikator pemberdayakan masyarakat dari aspek pemenuhan kebutuhan dasar, peningkatan pengetahuan, peningkatan keterampilan, sikap dan tindakan yang lebih baik.

Tabel 5. juga menunjukkan terdapat hubungan yang sangat signifikan $(p<0,01)$ antara media antarpribadi dan media publik. Hal ini menunjukkan bahwa indikator media antarpribadi dan media publik yang digunakan dengan tepat akan meningkatkan pemberdayaan masyarakat. Melalui media antarpribadi dan media publik tersebut 
Tabel 5

Koefisien korelasi antara indikator komunikasi, pesan, saluran dengan pemberdayaan masyarakat

\begin{tabular}{|c|c|c|c|c|c|}
\hline \multirow[t]{2}{*}{ Indikator/ Peubah } & \multicolumn{5}{|c|}{$\begin{array}{c}\text { Koefisien korelasi rank Spearman }\left(r_{s}\right) \text { pada } \\
\text { Masyarakat }\end{array}$} \\
\hline & $\begin{array}{c}\text { Memenuhi } \\
\text { kebutuhan } \\
\text { dasar }\end{array}$ & $\begin{array}{c}\text { Memiliki } \\
\text { pengetahuan }\end{array}$ & $\begin{array}{c}\text { Memiliki } \\
\text { keterampilan }\end{array}$ & $\begin{array}{l}\text { Memiliki } \\
\text { sikap }\end{array}$ & Tindakan \\
\hline $\begin{array}{l}\text { KOMUNIKATOR } \\
\text { Kredibilitas }\end{array}$ & $0.267^{* *}$ & $0.466^{* *}$ & $0.238^{* *}$ & $0.353^{* *}$ & $0.396^{* *}$ \\
\hline Daya Tarik Sumber & $0.218^{* *}$ & $0.469^{* *}$ & $0.145^{*}$ & $0.409^{* *}$ & $0.372^{* *}$ \\
\hline Kekuasaan & $0.241^{* *}$ & $0.396^{* *}$ & $0.227^{* *}$ & $0.519^{* *}$ & $0.473^{* *}$ \\
\hline Pikiran baik & $0.662^{* *}$ & $0.565^{* *}$ & $0.551^{* *}$ & $0.538^{* *}$ & $0.547^{* *}$ \\
\hline Akhlak Yang baik & $0.671^{* *}$ & $0.571^{* *}$ & $0.544^{* *}$ & $0.541^{* *}$ & $0.546^{* *}$ \\
\hline Maksud yang baik & $0.318^{* *}$ & $0.455^{* *}$ & $0.257^{* *}$ & $0.508^{* *}$ & $0.456^{* *}$ \\
\hline $\begin{array}{l}\text { PESAN } \\
\text { Perencanaan program }\end{array}$ & $-0.404^{* *}$ & $-0.415^{* *}$ & $-0.249^{* *}$ & $-0.353^{* *}$ & $-0.404^{* *}$ \\
\hline Pesan relevan, & $0.182^{* *}$ & $0.211^{* *}$ & $0.500^{* *}$ & $0.476^{* *}$ & $0.182^{* *}$ \\
\hline Ada kebaruan/novelty & $0.136^{*}$ & $0.145^{*}$ & $0.428^{* *}$ & $0.384^{* *}$ & $0.136^{*}$ \\
\hline Dapat dipercaya & $0.192^{* *}$ & $0.207^{* *}$ & $0.522^{* *}$ & $0.495^{* *}$ & $0.192^{* *}$ \\
\hline Mudah dimengerti, & $0.136^{*}$ & $0.148^{*}$ & $0.539^{* *}$ & $0.507^{* *}$ & $0.136^{*}$ \\
\hline $\begin{array}{l}\text { Memecahkan permasalahan } \\
\text { pengguna }\end{array}$ & $0.165^{* *}$ & $0.176^{* *}$ & $0.506^{* *}$ & $0.510^{* *}$ & $0.165^{* *}$ \\
\hline $\begin{array}{l}\text { SALURAN } \\
\text { Media antar pribadi }\end{array}$ & $0.891^{* *}$ & $0.392^{* *}$ & $0.737^{* *}$ & $0.397^{* *}$ & $0.389^{* *}$ \\
\hline Media kelompok & -0.021 & 0.085 & -0.114 & -0.002 & -0.041 \\
\hline Media publik & $0.299^{* *}$ & $0.330^{* *}$ & $0.257^{* *}$ & $0.244^{* *}$ & $0.235^{* *}$ \\
\hline Media massa & $-0.246^{* *}$ & $-0.196^{* *}$ & $-0.211^{* *}$ & $-0.167^{* *}$ & $-0.252^{* *}$ \\
\hline
\end{tabular}

Hasil Olahan, 2015

Keterangan: $* *$ signifikan pada $\mathrm{P}<0,01$ dan $*$ signifikan pada $\mathrm{P}<0,0$

masyarakat semakin meningkat kemampuan memenuhi kebutuhan dasar, meningkatan pengetahuan, meningkatkan keterampilan, sikap dan tindakan. Kemudian terdapat hubungan yang sangat signifikan $(p<0,01)$ dengan arah negatif antara media massa dengan pemberdayaan masyarakat. Hal ini menunjukkan media massa tidak digunakan oleh pegawai CSR PTPN V dalam usaha pemberdayaan masyarakat.

Tabel 6 menunjukkan bahwa indikator komunikator secara keseluruhan terdapat hubungan yang sangat signifikan $(p<0,01)$ indikator citra perusahaan yaitu indikator ekonomi dan sosial. Hal ini mengindikasi bahwa semakin sering indikator komunikator dilakukan akan dapat meningkatkan citra perusahaan dari aspek ekonomi dan sosial.

Tabel 6 memperlihatkan bahwa sebagian besar terdapat hubungan yang sangat signifikan $(p<0,01)$ antara indikator pesan dengan indikator ekonomi dan sosial. Hal ini mengindikasi bahwa semakin indikator pesan ditingkatkan maka dapat meningkatkan citra perusahaan dari aspek ekonomi dan sosial. Kecuali indikator perencanaan program terdapat hubungan yang sangat signifikan $(p<0,01)$ dengan arah yang negatif antara indikator ekonomi dan berhubungan signifikan dengan indikator sosial citra perusahaan. Hal ini mengindikasikan bahwa perencanaan program tidak diaplikasikan untuk mendapatkan citra perusahaan.

Tabel 6 menunjukkan bahwa terdapat hubungan yang sangat signifikan $(p<0,01)$ antara indikator media antarpribadi dan media publik dengan indikator ekonomi dan sosial. Hal ini mengindikasikan bahwa semakin sering indikator media antarpribadi dan media publik digunakan akan dapat meningkatkan citra perusahaan dari aspek ekonomi dan sosial. Kemudian, terdapat hubungan yang sangat signifikan $(p<0,01)$ dengan arah negatif antara indikator media antarpribadi dengan indikator lingkungan. Hal ini mengindikasikan bahwa semakin sering berkomunikasi melalui media antarpribadi maka semakin kurang membahas tentang lingkungan atau sebaliknya. Seterusnya terdapat hubungan yang sangat signifikan $(p<0,01)$ dengan arah negatif antara indikator 


\section{Tabel 6 \\ Koefisien korelasi antara indikator komunikasi, pesan, saluran dengan citra perusahaan}

\begin{tabular}{lccc}
\hline Indikator/ Perubah & \multicolumn{3}{c}{$\begin{array}{l}\text { Koefisien korelasi } \\
\text { Perusahaan }\end{array}$} \\
\cline { 2 - 4 } & Ekonomi & Sosial & Lingkungan \\
\hline KOMUNIKATOR & $0.453^{* *}$ & $0.164^{* *}$ & 0.094 \\
Kredibilitas & $0.955^{* *}$ & $0.170^{* *}$ & 0.098 \\
Daya Tarik Sumber & $0.296^{* *}$ & $0.270^{* *}$ & 0.048 \\
Kekuasaan & $0.364^{* *}$ & $0.349^{* *}$ & -0.107 \\
Pikiran baik & $0.382^{* *}$ & $0.362^{* *}$ & -0.067 \\
Akhlak Yang baik & $0.267^{* *}$ & $0.344^{* *}$ & 0.094 \\
Maksud yang baik & $-0.365^{* *}$ & $-0.141^{*}$ & -0.026 \\
PESAN & $0.381^{* *}$ & $0.268^{* *}$ & 0.071 \\
Perencanaan program & $0.569^{* *}$ & $0.217^{* *}$ & 0.038 \\
Pesan relevan, & $0.390^{* *}$ & $0.279^{* *}$ & 0.078 \\
Ada kebaruan/novelty & $0.327^{* *}$ & $0.222^{* *}$ & 0.065 \\
Dapat dipercaya & $0.337^{* *}$ & $0.227^{* *}$ & 0.020 \\
Mudah dimengerti, & $0.131^{*}$ & $0.299^{* *}$ & $-0.216^{* *}$ \\
Memecahkan permasalahan pengguna & $0.125^{*}$ & -0.013 & -0.035 \\
SALURAN & $0.345^{* *}$ & $0.313^{* *}$ & -0.089 \\
Media antar pribadi & $-0.284^{* *}$ & $-0.496^{* *}$ & 0.078 \\
Media kelompok & & & \\
Media publik & & & \\
Media massa & & &
\end{tabular}

Hasil Olahan, 2015

Keterangan: ** signifikan pada $\mathrm{P}<0,01$ dan $*$ signifikan pada $\mathrm{P}<0,05$

media massa dengan indikator ekonomi dan sosial. Hal ini mengindikasikan bahwa semakin sering berkomunikasi melalui media massa maka semakin kurang membahas tentang ekonomi dan sosial atau sebaliknya.

\section{Simpulan dan Saran}

Berdasarkan pembahasan maka dapat disimpulkan antara lain: (1) Implementasi komunikasi dalam CSR PTPN V untuk pemberdayaan masyarakat dan membangun citra positif secara umum adalah baik. Namun ada beberapa hal yang masih perlu dibenahi yaitu pegawai CSR PTPN V dan Dinas Koperasi dan UMKM Provinsi Riau tidak menggunakan media massa sama sekali untuk menginformasikan bantuan dana CSR PTPN V. Hal ini menyebabkan masyarakat tidak mengetahui tentang program bantuan pinjaman tersebut. Kemudian, pegawai CSR PTPN $V$ tidak melibatkan masyarakat pada proses perencanaan program. Hal ini menyebabkan komunikasi yang terjadi masih top down (satu arah). Selanjutnya pegawai CSR PTPN V tidak menyampaikan tentang pengelolaan lingkungan dalam aktivitas komunikasi dengan masyarakat. (2) Terdapat hubungan yang sangat signifikan $(p<0,01)$ antara peubah komunikator, pesan, saluran komunikasi dengan peubah pemberdayaan masyarakat dan citra perusahaan. Secara umum terdapat hubungan yang sangat signifikan $(p<0,01)$ antara indikator komunikator, pesan, saluran komunikasi dengan peubah pemberdayaan masyarakat dan citra perusahaan, namun ada sebagian kecil indikator tidak terdapat hubungan dan berhubungan sangat signifikan $(p<0,01)$ dengan arah negatif.

Berdasarkan simpulan tersebut disarankan kepada perusahaan dan instansi terkait perlu menggunakan media massa untuk menginformasikan program CSR PTPN $\checkmark$ kepada masyarakat. Kemudian, sebaiknya melibatkan masyarakat dalam perencanaan untuk meningkatkan kualitas komunikasi antara perusahan dan komunitas, sehingga pemberdayaan masyarakat akan lebih maksimal lagi. Pegawai CSR PTPN V perlu menyampaikan pengelolaan lingkungan kepada masyarakat untuk meningkatkan citra postif perusahan di mata masyarakat.

\section{Daftar Pustaka}

Agle, B. R., R. K. Mitchell and J. A. Sonnenfeld: 
(1999), 'Who Matters to CEOs? An Investigation of Stakeholder Attributes and Salience, Corporate Performance, and CEO Values', Academy of Management Journal 42(5), 507-525.

Ardianto, E. (2007). Public Relations Praktis. Bandung. Widya Padjajaran

Argandona, $A$. and $H$. von Weltzien Hoivik: (2010), 'Corporate Social Responsibility: One Size Does Not Fit All. Collecting Evidence from Europe', Journal of Business Ethics 89 (Suppl. 3), 221-234.

Cahyati, Witri (2008) Implementasi "Corporate Social Responsibility" Dalam

Pembentukan Citra Pt Pertamina Up III Bandung. Mimbar Vol. 24, No. 2 (Juli Desember 2008) ; 165-176

Cangara H. (2012). Pengantar Ilmu Komunikasi. Jakarta (ID). Raja Grafindo Persada.

Cangara H. (2013). Perencanaan \& Strategi Komunikasi. Jakarta (ID). Raja Grafindo Persada.

Chaudhri V, Wang J. (2007). Communicating corporate social responsibility on the Internet: A case study of the top 100 information technology companies in India. Management Communication Quarterly 21: 232. doi: $10.1177 / 0893318907308746$.

Freeman I, Hasnaoui A. (2011). The meaning of corporate social responsibility: the vision of four nations, Journal of Business Ethics 100:419-443. doi 10.1007/s10551-0100688-6.

Hasbullah T. (2012). Desain Strategi Tanggung Jawab Sosial Perusahaan Dalam Pemberdayaan Ekonomi Masyarakat dan Sumber Daya Pesisir Kota Bontang (Studi Kasus PT. Pupuk Kaltim). (disertasi). Bogor (ID). Institut Pertanian Bogor.

Kotler, Philip. (2005). Manajemen Pemasaran. Edisi Bahasa Indonesia. Prenhallindo, Jakarta.

Ligety G, Oravecz 'A. (2009). CSR communication of corporate enterprises in Hungary. Jurnal Etika Bisnis. 84: 137-149. doi 10,1007/ s10551-008-9678-3

Moreno A, Capriotti P. (2009). Communicating CSR, citizenship and sustainability on the web. Journal of Communication Management. 13 (2):157-175.

Nasdian FT. (2014). Pengembangan Masyarakat. Jakarta: Yayasan Pustaka Obor Indonesia.

Nielsen AE, Thomsen C. (2009). CSR communication in small and mediumsized enterprises A study of the attitudes and beliefs of middle managers. Corporate Communications: An International Journal. 14(2):176-189.

Peraturan Menteri Negara Badan Usaha Milik Negara (BUMN) No: PER 236/MBU/2003 tanggal tanggal 17 Juni 2003

Peraturan Menteri Negara Badan Usaha Milik Negara (BUMN) No: PER 05/MBU/2007 tanggal 27 April 2007 Pasal 9.

[PTPN] Perseroan Terbatas Perkebunan
Nusantara (2013) Laporan Manajemen PKBL 2013

[PTPN] Perseroan Terbatas Perkebunan Nusantara (2014). Dokumentasi Program CSR Bidang Program Kemitraan di Pekanbaru Tahun 2010-2014.

Sharlene R. (2012). Corporate social responsibility in post-apartheid South Africa. Social Responsibility Journal.8(2):270-288.

Situmeang IVO. (2012). Komunikasi Organisasi Melalui Kegiatan Tanggungjawab Sosial Perusahaan (Kasus PT Pertamina Refinery Unit VI Balongan). [Disertasi]. Bogor Institut Pertanian Bogor.

Suharto E. (2005). Membangun Masyarakat Memberdayakan Masyarakat: Kajian Strategis Pembangunan Kesejahteraan Sosial \& Pekerjaan Sosial. Bandung: Refika Aditama.

Suherman, Maman (2006) Peranan Corporate Sosial Responsibility (CSR) dalam Menurunkan Angka Kemiskinan Di Jawa Barat. Mimbar Vol 22, No.3 (Juli September 2006) ; $317-332$

Sumaryo, (2009) Implementasi Tanggungjawab Sosial Perusahaan (Corporate Social Responsibility) dalam Pemberdayaan dan Peningkatan Kesejahteraan Masyarakat: Kasus di Provinsi Lampung. (Disertasi). Bogor Institut Pertanian Bogor.

Syahyuti. (2006). 30 Konsep Penting dalam Pembangunan Pedesaan dan Pertanian. Jakarta (ID): Bina Rena Pariwara.

Takano K. (2013). Communicating CSR: Case study of japanese food industry. Journal International Bisnis dan Manajemen. 8(9) doi:10.5539/ijbm.v8n9p111

Tewari R, Dave D. (2012). Corporate social responsibility: Communication through sustainability reports by Indian and multinational companies. Global Business Review. 13(3) 393-405. doi: 10.1177/097215091201300303.

Turban, D. B. and D. W. Greening: (1997), 'Corporate Social Performance and Organizational Attractiveness to Prospective Employees', Academy of Management Journal 40(3), 658-672

Undang-Undang No. 40 tahun 2007, Pasal 74 yaitu Undang-Undang tentang Perseroan Terbatas.

Vardiansyah D. (2004). Pengantar IImu Komunikasi_Pendekatan Taksonomi Konseptual. Depok: Ghalia Indonesia.

Verboven H. (2011). Communicating CSR and business identity in the chemical industry through mission slogans. Business Communication Quarterly 74: 415. doi: $10.1177 / 1080569911424485$.

Weitzner, D. and J. Darroch: (2009), Why Moral Failures Precede Financial Crises, Critical Perspectives on International Business 5(1/2), 6-13.

Wiryanto. (2005). Pengantar IImu Komunikasi. Cetakan Keempat. Jakarta: Grasindo 